\title{
Determination of Integrity, Stability and Density of the DNA Layers Immobilised at Glassy Carbon and Gold Electrodes Using Ferrocyanide
}

John Colleran

Technological University Dublin, john.colleran@tudublin.ie

Anna Banasiak

Technological University Dublin, Anna.Banasiak@TUDublin.ie

Follow this and additional works at: https://arrow.tudublin.ie/scschcpsart

Part of the Materials Chemistry Commons

\section{Recommended Citation}

Banasiak, A. \& Colleran, J. (2020) Determination of Integrity, Stability and Density of the DNA Layers Immobilised at Glassy Carbon and Gold Electrodes Using Ferrocyanide, Electroanalysis, 2020, 32 (10) 2220-2230 DOI:10.1002/elan.202060077

This Article is brought to you for free and open access by the School of Chemical and Pharmaceutical Sciences at ARROW@TU Dublin. It has been accepted for inclusion in Articles by an authorized administrator of ARROW@TU Dublin. For more information, please contact arrow.admin@tudublin.ie, aisling.coyne@tudublin.ie, gerard.connolly@tudublin.ie.

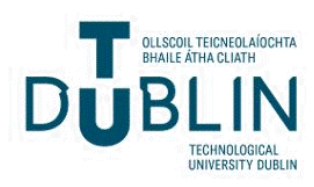




\title{
Determination of Integrity, Stability and Density of the DNA Layers Immobilised at Glassy Carbon and Gold Electrodes Using Ferrocyanide
}

\author{
Anna Banasiak ${ }^{[a]}$ and John Colleran*[a, b]
}

\begin{abstract}
The technique chosen to immobilise DNA onto electrodes can determine the density and stability of the resultant immobilised layer. DNA-modified electrodes were prepared using four common DNA immobilisation methods and characterised using ferrocyanide. The negatively charged DNA strands should repel ferrocyanide anions. The DNA layers created using adsorption at
\end{abstract}

glassy carbon electrodes were unstable, while those created through chemisorption of thiol-modified DNA onto gold electrodes were repeatable and stable, and returned, on average, $94 \%$ repulsion of the probe. The presented results show how the immobilisation protocol, and DNA type, affects the stability, repeatability, and integrity of resultant DNA layers.

Keywords: biosensors · DNA · ferrocyanide · immobilization · interactions

\section{Introduction}

Electrochemical DNA sensors can be used for various environmental and medical purposes, specifically, to detect pollutants $[1,2]$, to investigate the interactions between drugs $[3,4]$, drug candidates $[5,6]$ and proteins $[7,8]$ with various types of immobilised DNA, to evaluate the protective effect of certain compounds on DNA $[9,10]$, and to detect specific mutations in DNA $[11,12]$.

DNA-modified electrodes (DNA-ME) should consist of optimally dense, stable and reproducibly immobilised DNA layers to create reliable sensors suitable for analytical applications. Partial surface coverage and poor layer stability (desorption of the DNA layer over time) can result in unmodified regions on the electrode surface where direct interactions between the bare electrode and target molecules can occur. Electrochemical data returned, misinterpreted as interactions between DNA and target molecules, could easily lead to incorrect conclusions. In addition to DNA layer integrity, the DNA surface density is a key factor in the creation of DNA sensors with the desired sensor properties. While sensors returning low DNA surface coverages are reported to have low sensitivities, overly dense DNA surface coverage can sterically hinder interactions between DNA and target molecules [13-15]. Immobilised DNA layers should be optimised and interrogated, prior to use as sensors, as the integrity, density and stability of the DNA layer strongly affect the performance of the resultant DNA sensor. Surprisingly, the characterisation of immobilised DNA layers is rarely performed or reported upon.

The standard and widely reported DNA immobilisation methods, such as physical adsorption, electrochemical adsorption and covalent attachment at carbon electrodes, and the creation of self-assembled monolayers (SAM) at gold electrodes, present characteristics which determine the properties of resultant DNA sensors.

Physical adsorption of DNA onto an electrode surface is promoted through the drop casting of, or by immersing the electrode into, a DNA solution. A range of DNA concentrations and drop cast volumes used with carbon electrodes of various electrode areas are reported in the literature; $5 \mu \mathrm{L}$ of $0.1 \mathrm{~g} / \mathrm{L}$ DNA on the electrode of $25 \mathrm{~mm}^{2}$ area $\left(2 \times 10^{-6} \mathrm{~g} / \mathrm{cm}^{2}\right)[5,10]$, through $5 \mu \mathrm{L}$ of $35 \mathrm{~g} / \mathrm{L}$ DNA on $1.5 \mathrm{~mm}$ diameter electrode $\left(9.91 \times 10^{-3} \mathrm{~g} / \mathrm{cm}^{2}\right)$ [16] and $20 \mu \mathrm{L}$ of $0.5 \mathrm{~g} / \mathrm{L}$ DNA on $3 \mathrm{~mm}$ diameter electrode $\left(1.42 \times 10^{-4} \mathrm{~g} / \mathrm{cm}^{2}\right)$ [17] up to $80 \mu \mathrm{L}$ of $35 \mathrm{~g} / \mathrm{L}$ DNA on $6 \mathrm{~mm}$ diameter electrode $\left(9.91 \times 10^{-3} \mathrm{~g} / \mathrm{cm}^{2}\right)$ [18]. The adsorption times reported in the literature vary from several minutes to 24 hours $[19,20]$. The Brett group showed how different DNA immobilisation concentrations and times affect the thickness and integrity of the layer $[19,21]$, concluding that thick and dense DNA films can be immobilised using high concentrations of DNA and long immobilisation times. Physical adsorption of DNA is possible on various surfaces (mercury [22], carbon [23], gold electrodes [24,25]) and requires no

[a] Dr. A. Banasiak, Dr. J. Colleran

Applied Electrochemistry Group, Technological University Dublin, FOCAS Institute, Camden Row, Dublin 8, D08 CKP1 Ireland

Tel: +35314024682

E-mail: john.colleran@tudublin.ie

[b] Dr. J. Colleran

School of Chemical and Pharmaceutical Sciences, Technological University Dublin, City Campus - Kevin Street, Dublin 8, D08 NF82 Ireland

Supporting information for this article is available on the WWW under https://doi.org/10.1002/elan.202060077 
reagents other than DNA [26]. However, the DNA layer physically adsorbed at carbon or gold electrodes can easily desorb during practical application [26], facilitating non DNA-specific interactions between the electrode and target species.

In the electrochemical adsorption method, a relatively positive potential is applied to an electrode, for a given time, electrostatically attracting the negatively charged DNA backbone [27-30]. The features of the DNA layer depend on the concentration, and form, of DNA, the buffer type and $\mathrm{pH}$, the applied potential and the potential application time [21,31]. Various conditions are reported in the literature, for example, adsorption of $0.30 \mathrm{~g} / \mathrm{L}$ of DNA at $+0.2 \mathrm{~V}$ vs. SCE for $15 \mathrm{~min}$ [32] and $34 \mathrm{~g} / \mathrm{L}$ of DNA at $+1.3 \mathrm{~V}$ vs. SCE for $15 \mathrm{~min}$ [33]. In this approach, DNA adsorbs at multiple points to the electrode surface through the negatively charged DNA backbone significantly limiting the configurational freedom of the DNA. Additionally, any interactions between DNA and target molecules can offset the electrostatic interactions between DNA and the electrode surface promoting desorption of the DNA layer [26,34,35].

In the covalent attachment method, one of the DNA strands' termini, $5^{\prime}$ or $3^{\prime}$, is covalently bound, through a linker, to the electrode surface. Attachment of DNA through a linker (not through the DNA backbone) ensures configurational freedom of the DNA strands. Thus, any changes in DNA conformation, on interaction with a target molecule, should not disrupt the connection between DNA and the electrode surface [26,36]. However, the rate of electron transfer between the electrode and the target molecule via DNA base pairs (long-range electron transfer) is significantly influenced by the length of the linker [37]. Moreover, the stability of the DNA-ME can also depend on the stability of the linker-electrode bond. Thiol linkers, for example, are electroactive at high cathodic and anodic potentials [38]. Any DNA strands attached to the electrode through the thiol linkers will desorb from the surface if high potentials are used. Nevertheless, the creation of self-assembled monolayers on gold surfaces is a popular approach in preparing DNAME. Single-stranded and amine-modified DNA can be attached through thiol/EDC/NHS linkers [39,40], biotinylated DNA can be linked through thiol/EDC/NHS/ streptavidin linkers [36], while thiolated DNA can be attached directly to the gold surfaces [37,41-44]. Carbon electrodes require surface activation to decorate with functional groups suitable for coupling with DNA through a linker [26]. Similarly, as with immobilisation through adsorption, there are numerous protocols reported in the literature for immobilisation of DNA through covalent attachment. The protocols differ in the electrode functionalisation reagents, the type and concentrations of DNA and linkers, and in the coupling reaction times [40,45-48].

In all DNA sensors, the DNA backbone is negatively charged and Coulombic repulsion inevitably leads to spacing between immobilised DNA strands. These spaces, referred to as 'pin holes', are unmodified electrode areas where non DNA-specific interactions with target molecules can occur. The effect of pin holes can be minimised by backfilling the active sites of the bare electrode with smaller molecules. Alkanethiols, thus far, have been the most widely used reagents to backfill pinholes at gold electrodes $[24,37,41]$ but the use of aromatic thiols is starting to gain traction $[13,49,50]$. Aromatic thiol monolayers are characterised by strong structural rigidity and the intermolecular interactions between neighbouring phenyl moieties facilitate dense monolayer packing. Miranda-Castro et al. [13] presented an interesting approach in using a carboxylic group functionalised aromatic thiol self-assembled monolayer (SAM) to which DNA was covalently attached through an EDC/NHS linker. The authors reported a reproducible sensor comprised of homogenously distributed DNA strands which returned high sensitivities towards bacterial RNA detection. The sensing and stability characteristics of this sensor were reported to be significantly improved when compared to DNA sensors created using the traditional backfilling method (immobillsation of DNA followed by backfilling with thiol). Backfilling at carbon electrodes, after DNA immobilisation, to maximise surface coverage, is not widely reported. Hashimoto et al. [51] used physical adsorption of stearylamine as the amine group is positively charged at $\mathrm{pH} 7\left(\mathrm{pKa}=10.6\right.$ at $25^{\circ} \mathrm{C}$ [52]) and, hence, can block positively charged target species. DNA$\mathrm{ME}$ created to investigate interactions with proteins can be backfilled via physical adsorption of bovine serum albumin [53,54].

In this work, the redox indicator, ferrocyanide, was used to examine the DNA layers at DNA-ME prepared using several standard immobilization techniques. The redox indicator is negatively charged and, hence, should be repelled by the negatively charged DNA backbone. Therefore, the oxidation of $\left[\mathrm{Fe}^{\mathrm{II}}(\mathrm{CN})_{6}\right]^{4-}$ should, in theory, be largely inhibited at DNA sensors with extensive coverage of DNA or DNA plus a backfilling agent. Here, we express the degree of the repulsion of $\left[\mathrm{Fe}^{\mathrm{II}}\right.$ $\left.(\mathrm{CN})_{6}\right]^{4-}$ at DNA-modified electrodes as a percentage value. The ferrocyanide redox behaviour at the DNA-ME can reveal information about the critical features, such as stability, repeatability and integrity of the resultant DNA layers created. The aim of this work, is to encourage the electrochemical community to interrogate the stability and integrity of DNA layers in reported DNA sensors prior to further use. This would ensure that observed electrochemical responses are associated with immobilised DNA - target molecule interactions and not due to interactions between target molecules and unmodified regions of the electrode surface (non DNA-specific).

\section{Experimental}

\subsection{Materials}

Salmon testes double-stranded DNA (ST DNA) and two complementary single-stranded 30 base pair DNA oligo- 
nucleotides (Oligo DNA), were purchased from SigmaAldrich. The Oligo DNA had the following sequences:

- Thiol-modified strand: $\mathrm{SH}-\left(\mathrm{CH}_{2}\right)_{6}-5^{\prime}$ AGTACAGTCATCGCTTAATTATCGTACGTA 3'

- Complementary strand: 3'TCATGTCAGTAGCGAATTAATAGCATGCAT 5'

The Oligo DNA strands were hybridised prior to use according to the protocol described in S-1, Supplementary Information - SI.

The purity of ST DNA was determined by measuring absorbances at $260 \mathrm{~nm}, 280 \mathrm{~nm}$ and $230 \mathrm{~nm}$. The A260/ A230 ratio was 2.2, while A260/A280 was 1.8 indicating that DNA was free of contamination. Nuclease-free water was used to prepare $1 \times \mathrm{TE}$ buffer (a mixture of $10 \mathrm{mM}$ Tris- $\mathrm{HCl}, \mathrm{pH}$ 8.0, and $1 \mathrm{mM}$ EDTA, $\mathrm{pH}$ 8.0) required for the dilution of DNA. All other solutions were prepared using ultrapure water purified with a Milli-Q system. Argon gas of technical grade (Air Products) was used to deaerate solutions when required. All other chemicals were of analytical grade, namely, potassium phosphate monobasic and dibasic, sodium acetate, acetic acid, potassium ferrocyanide, nuclease-free water, Tris- $\mathrm{HCl}$, EDTA, magnesium sulfate, $N$-(3-Dimethylaminopropyl)$N^{\prime}$-ethylcarbodiimide (EDC) and $N$-Hydroxysuccinimide (NHS) (all Sigma-Aldrich), and p-toluenethiol 98\% (Fisher).

\subsection{Equipment}

The electrochemical measurements were performed on a $\mathrm{CH}$ Instruments $620 \mathrm{~A}$ potentiostat. Glassy carbon electrodes - GCE (3 mm diameter) and gold electrodes AuE ( $2 \mathrm{~mm}$ diameter), modified with DNA, were used as the working electrodes. A saturated calomel electrode (SCE) was used as the reference electrode, and a platinum wire as the counter electrode. The supporting electrolyte was either $0.2 \mathrm{M}$ acetate buffer (AcB), $\mathrm{pH}$ 5.0, containing $20 \mathrm{mM} \mathrm{MgSO}{ }_{4}\left(\mathrm{Mg}^{2+}\right)$ when required, or $0.05 \mathrm{M}$ phosphate buffer, $\mathrm{pH}$ 7.0, (PB).

\subsection{Preparation of Control and DNA-Modified Electrodes through Physical Adsorption at Glassy Carbon Electrodes (DNA-GCME ${ }_{P A}$ )}

The control electrode and DNA-GCME $E_{\mathrm{PA}}$ were prepared by drop casting $50 \mu \mathrm{l}$ of TE buffer and $0.90 \mathrm{~g} / \mathrm{L}$ ST DNA in TE buffer, respectively, onto a freshly polished GCE surface. The electrodes were left overnight to dry and then soaked in supporting electrolyte, for 30 minutes to remove any non-adsorbed DNA fragments.

\subsection{Preparation of Control and DNA-Modified} Electrodes through Electrochemical Adsorption at Glassy Carbon Electrodes (DNA-GCME EA $_{\text {) }}$

Different ST DNA concentrations and applied potential times were used to promote maximum surface coverage of DNA (S-2, SI). Ultimately, the DNA-GCME $E_{\mathrm{EA}}$ were created by immersing a clean GCE in a $0.2 \mathrm{M} A c B$ $\left(\mathrm{Mg}^{2+}\right)$, pH 5.0, containing $0.09 \mathrm{~g} / \mathrm{L}$ ST DNA, and holding at a potential of $+0.5 \mathrm{~V}$ vs. SCE for $20 \mathrm{~min}$. The relatively low anodic potential was used to prepare the DNA$\mathrm{GCME}_{\mathrm{EA}}$ as the application of high anodic potentials, for an extended period of time, can cause oxidative damage to DNA [32]. The electrodes were then washed in pure buffer to remove non-adsorbed DNA strands. The control electrode was prepared using the same procedure but in the absence of ST DNA.

\subsection{Preparation of Control and DNA-Modified Electrodes through Covalent Attachment Using a EDC/NHS Linker at Glassy Carbon Electrodes (DNA-GCME CA $_{\text {) }}$}

DNA-GCME $E_{C A}$ was prepared using three steps. Functionalisation of the GCE surface with carboxyl groups was performed by applying potential at $+1.8 \mathrm{~V}$ for 10 minutes and then $-1.0 \mathrm{~V}$ for 1 minute in $0.2 \mathrm{M} \mathrm{AcB}, \mathrm{pH}$ 5.0. The EDC/NHS linker was attached to the carboxyl groups by soaking the pre-treated electrode in $0.05 \mathrm{M} \mathrm{PB}, \mathrm{pH} 7.0$, containing $10 \mathrm{mM}$ EDC and $10 \mathrm{mM}$ NHS for 40 minutes. Finally, the ST DNA was coupled to the EDC/NHSmodified GC electrode by immersing the electrode in $0.05 \mathrm{M}$ PB, pH 7.0, containing $0.09 \mathrm{~g} / \mathrm{L}$ ST DNA for 30 minutes. Conditions for all steps were chosen based on obtained experimental data. The control electrode was a clean, bare GCE.

\subsection{Preparation of Control and DNA-Modified Electrodes through Chemisorption of Thiol-Modified Oligo DNA at Gold Electrodes (DANN-AuME)}

Thiol-modified Oligo DNA strands were first hybridised with a complementary DNA strand. DNA-AuME was then prepared by immersing the freshly cleaned gold electrode in $0.5 \mathrm{M} \mathrm{PB}, \mathrm{pH} 7.0$, containing $0.4 \mu \mathrm{M}$ of thiolmodified double-stranded Oligo DNA (overnight). The DNA strands immobilised at the electrode surface are likely to arrange in a random orientation - some bound through the thiol linker and some physically adsorbed at the surface $[24,41,55,56]$. The orientation of DNA strands can be manipulated somewhat by the application of a suitable potential [57-59]. Thereafter, the DNA strands immobilised at the electrode surface purported to be positioned in a more perpendicular orientation at the DNA-AuME (application of $-0.6 \mathrm{~V}$ vs. SCE, for $30 \mathrm{~s}$ ). Application of this potential for a short duration in high ionic strength solution does not cause desorption of DNA from the electrode surface or dehybridisation of the DNA strands (S-3, SI). The DNA-modified electrode was then immersed in a $1 \mathrm{mM}$ p-toluenethiol solution to backfill pin holes [44]. The control electrode was a clean, bare gold electrode. 


\subsection{Electrochemical Conditions}

The bare electrodes, the control electrodes, and the DNA-modified electrodes were characterised using $0.5 \mathrm{mM}\left[\mathrm{Fe}^{\mathrm{II}}(\mathrm{CN})_{6}\right]^{4-}$. The DNA-GCME ${ }_{\mathrm{PA}}$ and DNA$\mathrm{GCME}_{\mathrm{EA}}$ were prepared and characterised in AcB containing $\mathrm{Mg}^{2+}$, proposed to decrease the repulsive forces between neighbouring DNA strands $[60,61]$, maximising the DNA surface coverage and minimising desorption of the DNA strands while cycling through cathodic potentials. At the DNA-GCME $\mathrm{CA}_{\mathrm{A}}$ and DNAAuME, the DNA strands were attached to the electrode surface indirectly (through the linker) and cycling through cathodic potentials should not cause desorption of the DNA strands. The DNA-GCME ${ }_{C A}$ and DNA-AuME were then characterised in PB. All electrochemical measurements performed at the gold electrodes were carried out in deaerated solutions.

The square wave (SW) voltammetric measurements were used to interrogate the integrity of the immobilised DNA layers. The ferrocyanide oxidation peak currents obtained at the bare electrodes, under the given conditions, exhibit no repulsion, assigned as $0 \%$. The total absence of a $\left[\mathrm{Fe}^{\mathrm{II}}(\mathrm{CN})_{6}\right]^{4-}$ oxidation equates to a value of $100 \%$ due to complete repulsion. To calculate the percentage $\left[\mathrm{Fe}^{\mathrm{II}}(\mathrm{CN})_{6}\right]^{4-}$ repulsion the following equation was used:

$$
R \%=100 \%-\left(\frac{\text { Ip }, \text { me }}{\text { Ip }, \text { bare }} x 100 \%\right)
$$

where $\mathrm{R} \%$ is the relative percentage of $\left[\mathrm{Fe}^{\mathrm{II}}(\mathrm{CN})_{6}\right]^{4-}$ repulsion; $\mathrm{I}_{\mathrm{p}, \text { bare }}$ is the $\left[\mathrm{Fe}^{\mathrm{II}}(\mathrm{CN})_{6}\right]^{4-}$ oxidation peak current registered at the bare electrode $[\mu \mathrm{A}]$ at given condition; $\mathrm{I}_{\mathrm{p}, \mathrm{me}}$ is the $\left[\mathrm{Fe}^{\mathrm{II}}(\mathrm{CN})_{6}\right]^{4-}$ oxidation peak current registered at each modified electrode created using the indicated immobilisation method $[\mu \mathrm{A}]$. The values of $\mathrm{I}_{\mathrm{p} \text {,bare }}$ and $\mathrm{I}_{\mathrm{p}, \mathrm{me}}$ were determined in the same electrolyte.

\section{Results and Discussion}

Negatively charged ferrocyanide ions should be repelled by the negatively charged DNA layer immobilised at the electrode surface. Hence, at DNA-ME presenting extensive surface coverages, the ferrocyanide redox wave is expected to be significantly diminished or absent. The degree of $\left[\mathrm{Fe}^{\mathrm{II}}(\mathrm{CN})_{6}\right]^{4-}$ repulsion indicates the integrity of the DNA layer. The $\left[\mathrm{Fe}^{\mathrm{II}}(\mathrm{CN})_{6}\right]^{4-}$ oxidation peak can also reveal the repeatability and stability of the DNA layer immobilised at the electrode surface. Due to the inherent differences in the DNA forms used to create DNA sensors, a direct comparison of DNA sensors is futile and is not attempted here. Nonetheless, the integrities of immobilised DNA layers, probed using ferrocyanide, are directly comparable.

\subsection{Characterisation of DNA-GCME ${ }_{\mathrm{PA}}$}

The electrochemical characterisation was performed by immersing the DNA-GCME $E_{\mathrm{PA}}$ and control electrodes (GCE drop cast with TE buffer without DNA) in $0.5 \mathrm{mM}$ ferrocyanide. Using cyclic voltammetry, the redox waves for $\left[\mathrm{Fe}^{\mathrm{II} / \mathrm{III}}(\mathrm{CN})_{6}\right]^{4-/ 3-}$ were clearly visible at the bare and control electrodes (Figure 1). Ferrocyanide can undergo one electron oxidation to ferricyanide as follows:

$$
\left[\mathrm{Fe}^{\mathrm{II}}(\mathrm{CN})_{6}\right]^{4-} \leftrightarrows\left[\mathrm{Fe}^{\mathrm{III}}(\mathrm{CN})_{6}\right]^{3-}+\mathrm{e}^{-}
$$

The $I_{p, a} / I_{p, c}$ ratios obtained for the $\left[\mathrm{Fe}^{\mathrm{II} / I I I}(\mathrm{CN})_{6}\right]^{4-/ 3-}$ redox couple at these electrodes were close to unity. The $\Delta$ Ep values, $82 \mathrm{mV}$ and $136 \mathrm{mV}$ at the bare and control electrodes, respectively, were larger than predicted for an ideal $1 \mathrm{e}^{-}$reversible redox process, i. e. $59 \mathrm{mV}$. Hence, the redox processes occurring at these electrodes are quasireversible. The redox wave registered at the control electrode was smaller in magnitude, with a larger $\Delta \mathrm{Ep}$ value, compared to that at the bare electrode. It can be inferred that a thin TE buffer layer remained on the control electrode surface after the washing step, resulting in slight passivation. The $\Delta \mathrm{Ep}$ values registered for three independently prepared DNA-GCME $E_{\mathrm{PA}}$ were repeatable, $352+/-1.53 \mathrm{mV}$ (S-4, SI), and much larger than $\Delta \mathrm{Ep}$ registered at the control and bare electrode. Hence, the $\left[\mathrm{Fe}^{\mathrm{II} / I I \mathrm{II}}(\mathrm{CN})_{6}\right]^{4-/ 3-}$ redox reaction at the DNA-modified electrode was strongly hindered. This indicates that some ST DNA was immobilised on the electrode surface and the $\left[\mathrm{Fe}^{\mathrm{II}}(\mathrm{CN})_{6}\right]^{4-}$ redox indicator was repelled by the negatively charged ST DNA layer. Nevertheless, the presence of a redox wave at the DNA-modified electrode indicates that the integrity of the DNA layer is compromised. Consequently, if this DNA sensor was used to investigate DNA interactions, direct communication between the target molecules and unmodified regions of electrode surface is likely. Moreover, the immobilised

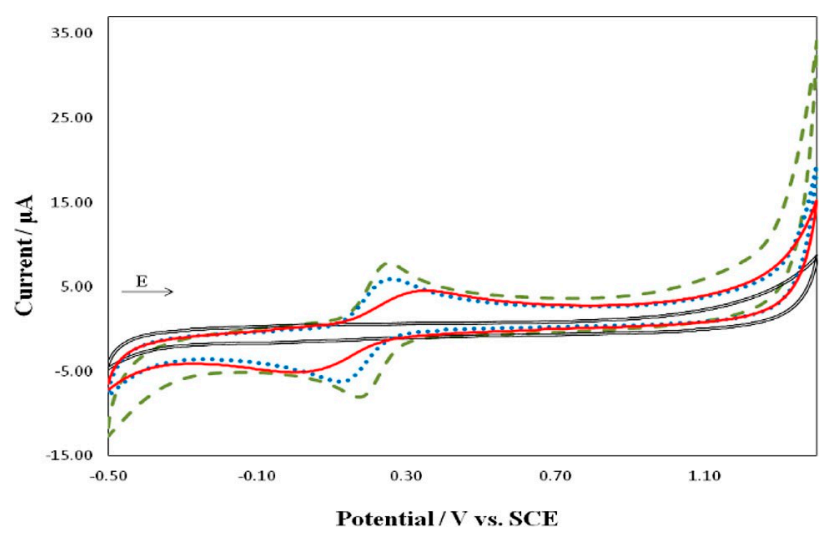

Fig. 1. Cyclic voltammograms registered in $0.2 \mathrm{M} \mathrm{AcB}\left(\mathrm{Mg}^{2+}\right)$, $\mathrm{pH}$ 5.0, at the DNA-GCME $\mathrm{PA}_{\mathrm{PA}}$ (black double trace), and in $0.5 \mathrm{mM}\left[\mathrm{Fe}^{\mathrm{II}}(\mathrm{CN})_{6}\right]^{4-}$ at the bare GCE (green dashed trace), the control electrode (blue dotted trace) and DNA-GCME $\mathrm{PA}_{\mathrm{PA}}$ (red solid trace), scan rate: $0.1 \mathrm{~V} / \mathrm{s}$. 
DNA layer was not stable over time (S-5, SI). Therefore, the electrochemical response of target molecules, registered at the DNA-ME, could change over time and lead to the misinterpretation of data. The lack of stability and presence of unmodified glassy carbon electrode active sites greatly limit the application of these types of DNA sensors.

\subsection{Characterisation of DNA-GCME ${ }_{E A}$}

The integrity of the immobilised DNA layer for the DNA-GCME $E_{\mathrm{EA}}$ was examined using the redox indicator, $\left[\mathrm{Fe}^{\mathrm{II}}(\mathrm{CN})_{6}\right]^{4-}$. A well-defined redox couple was clearly observed at the bare GC, the control and at the DNAGCME $_{\mathrm{EA}}$ electrodes (Figure 2). The bare and control (prepared in the same way as DNA-modified electrodes but in the absence of DNA) electrodes exhibited very similar peak currents $\left(\mathrm{I}_{\mathrm{p}, \mathrm{a}} / \mathrm{I}_{\mathrm{p}, \mathrm{c}} \sim 1\right)$ and profiles, returning $\Delta \mathrm{Ep}$ values of $82 \mathrm{mV}$ and $79 \mathrm{mV}$, respectively. Similar values of potential and current obtained at the bare and control electrodes, indicate that the application of the anodic potential to the electrode did not alter the faradaic response of the glassy carbon surface. The difference between the electrochemical profile of ferrocyanide registered at the control and DNA-modified electrodes is then associated with the presence of immobilised DNA and not with the application of the $+0.5 \mathrm{~V}$ potential for $20 \mathrm{~min}$. The $\triangle \mathrm{Ep}$ values registered at the DNA-GCME $\mathrm{EA}$, $225+/-1.00 \mathrm{mV}$, indicate that $\left[\mathrm{Fe}^{\mathrm{II}}(\mathrm{CN})_{6}\right]^{4-}$ ions are repelled somewhat by the immobilised ST DNA strands. The $\left[\mathrm{Fe}^{\mathrm{II}}(\mathrm{CN})_{6}\right]^{4-}$ redox profiles obtained for three freshly prepared DNA-GCME $E_{\mathrm{EA}}$ were almost identical; hence, the DNA-modified electrodes created by this method are repeatable $(\mathrm{S}-6, \mathrm{SI})$. Similar to DNA-GCME $\mathrm{PA}_{\mathrm{PA}}$, the presence of significant redox activity at the DNA$\mathrm{GCME}_{\mathrm{EA}}$ indicates that the integrity of the immobilised ST DNA layer is compromised, permitting $\left[\mathrm{Fe}^{\mathrm{II}}(\mathrm{CN})_{6}\right]^{4-}$ to interact directly with the electrode surface. A DNA

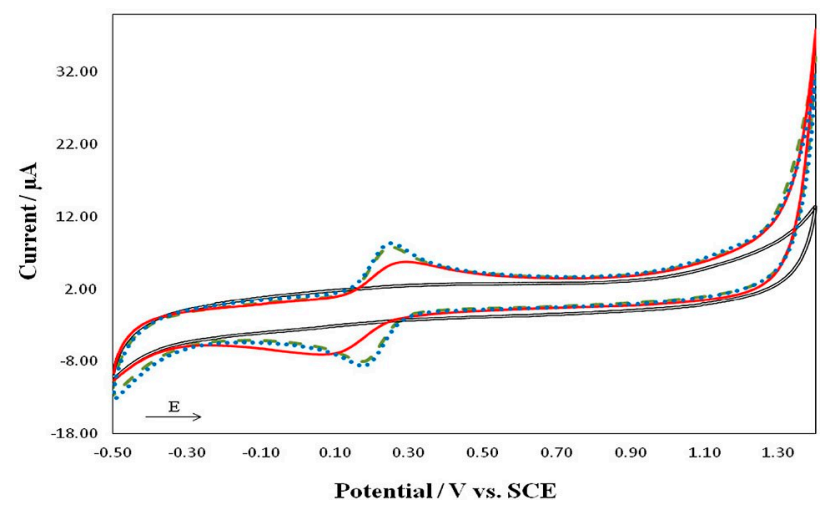

Fig. 2. Cyclic voltammograms registered in $0.2 \mathrm{M} \mathrm{AcB}\left(\mathrm{Mg}^{2+}\right)$, $\mathrm{pH}$ 5.0, at the DNA-GCME $\mathrm{EA}_{\mathrm{E}}$ (black double trace) and in $0.5 \mathrm{mM}\left[\mathrm{Fe}^{\mathrm{II}}(\mathrm{CN})_{6}\right]^{4-}$ at the bare electrode (green dashed trace), the control electrode (blue dotted trace), the DNA-GCME $\mathrm{EA}_{\mathrm{EA}}$ (red solid trace), scan rate: $0.1 \mathrm{~V} / \mathrm{s}$. sensor created through electrochemical adsorption would, thus, facilitate non DNA-specific interactions between the bare electrode surface and target species.

Moreover, the ST DNA layer at the DNA-GCME $E_{\mathrm{EA}}$ was not stable because the $\left[\mathrm{Fe}^{\mathrm{II}}(\mathrm{CN})_{6}\right]^{4-}$ electrochemical response was observed to change over short times (S-7, SI).

\subsection{Fabrication of DNA-GCME $\mathrm{CA}_{\mathrm{A}}$}

The covalent attachment method for GCE is based on three steps:

- electrochemical functionalisation of the GCE surface with carboxylate groups,

- covalent attachment of an EDC/NHS linker to the carboxylate groups,

- covalent attachment of the ST DNA to the EDC/NHS linker.

The mechanism for the covalent attachment of ST DNA to the functionalised GCE is presented in scheme 1. The reaction between EDC and the carboxyl groups results in the formation of the unstable o-acylisourea ester which is rapidly hydrolysed. In the presence of NHS, oacylisourea ester is converted to an NHS ester with a much longer half-life. A primary or secondary amine group in DNA can direct nucleophilic attack at the carbonyl group of the NHS ester, and a stable amide link is created between DNA and the electrode surface [62]. The DNA used in this procedure should have free amine groups in the structure similar to, for example, singlestranded DNA or amine-modified DNA. However, calf thymus dsDNA $[63,64]$ and fish sperm dsDNA [65] have also been used in this coupling procedure. Doublestranded DNA obtained from tissues can contain singlestrands, and is susceptible to fragmentation, to some degree, during the isolation or preparation processes [6668]; hence, some free primary or secondary amine groups are present in the DNA strands.

Conditions were investigated experimentally to obtain optimal and reproducible DNA layers (S-8, S-9 and S-11, $\mathrm{SI})$ and electrochemical characterisation was carried out using square wave voltammetry. All measurements were performed in $0.05 \mathrm{M}$ phosphate buffer, $\mathrm{pH} 7.0$ containing $0.5 \mathrm{mM}\left[\mathrm{Fe}^{\mathrm{II}}(\mathrm{CN})_{6}\right]^{4-}$.

\subsubsection{Electrochemical Functionalisation of the GCE Surface with Carboxylate Groups}

Carbon electrodes can be functionalised with carboxyl groups in various different ways, for example, through electrochemical oxidation of the surface $[26,47,69,70]$ or through electrodeposition of a polymer containing carboxyl groups in its structure [71,72]. Carboxyl groups $(-\mathrm{COOH})$ can be formed on a GC surface by applying a high positive potential to the bare electrode [70].

The application of $+1.8 \mathrm{~V}$ vs. SCE for $10 \mathrm{~min}$ resulted in the creation of a strongly oxidised GCE surface, likely resulting in the creation of surface-bound carboxyl 

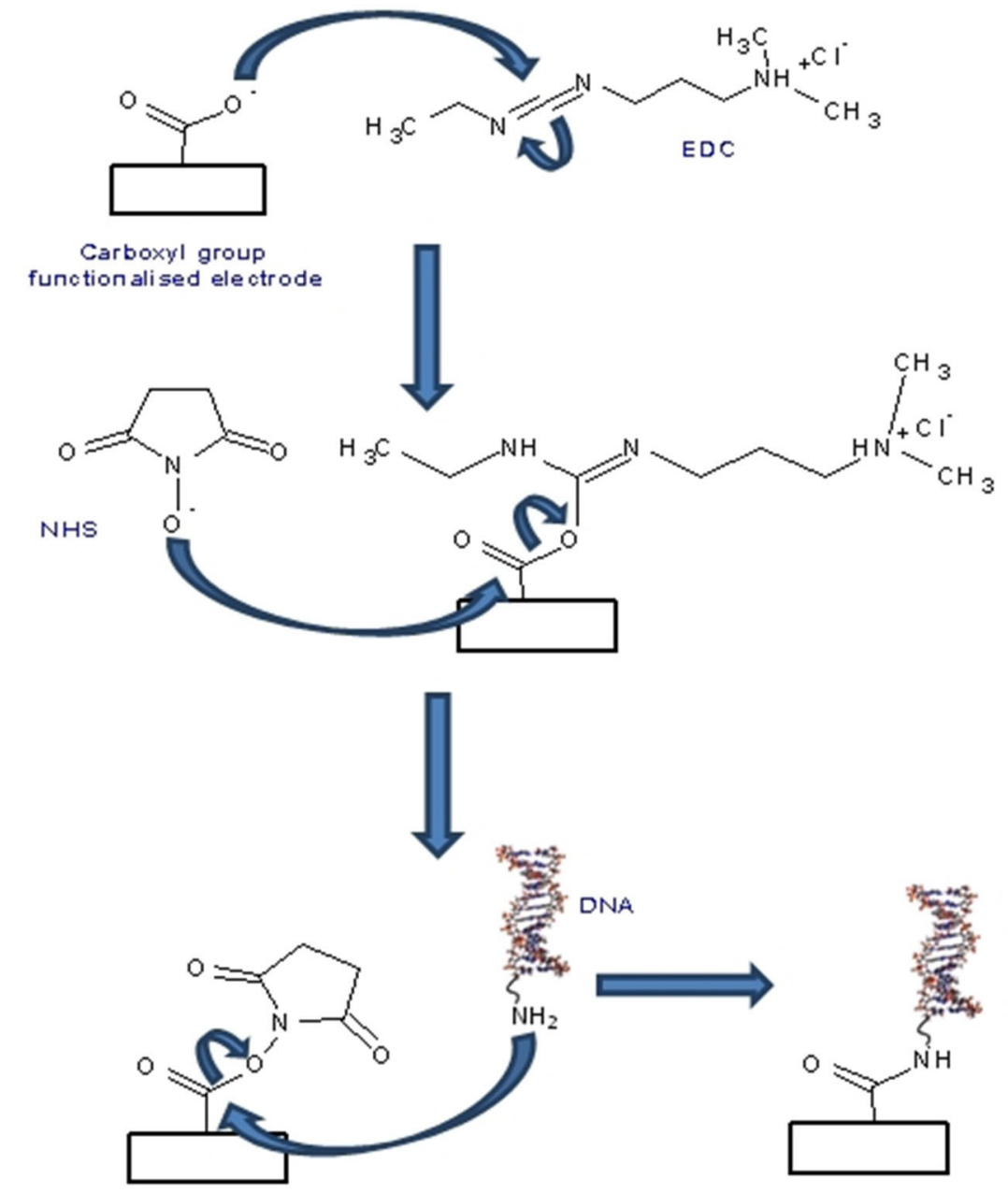

Scheme 1 . The mechanism of the carboxyl/EDC/NHS/DNA coupling reaction.

groups; however, the surface properties were not repeatable using these conditions (S-8, SI). An additional reduction step $(-1.0 \mathrm{~V}$ vs. SCE for $1 \mathrm{~min})$, stabilizing the electrode surface, was then added to the procedure. Increasing the holding times, for either of the reduction and oxidation steps, did not promote more extensive carboxyl group functionalisation (S-8, SI).

In this work, the final potentials found to produce repeatable electrode surfaces, rich in electrogenerated $-\mathrm{COOH}$ groups, were $+1.8 \mathrm{~V}$ vs. $\mathrm{SCE}$ for 10 minutes followed by $-1.0 \mathrm{~V}$ vs. $\mathrm{SCE}$ for $1 \mathrm{~min}$ in $0.2 \mathrm{M} \mathrm{AcB}$, pH 5.0.

The $\left[\mathrm{Fe}^{\mathrm{II}}(\mathrm{CN})_{6}\right]^{4-}$ oxidation peak current obtained at the electrode prepared using these oxidation and reduction conditioning steps (GCEox/GCEred) was visible but greatly diminished (approximately 65\%, Figure 3) and repeatable $(\mathrm{S}-8, \mathrm{SI})$. Although the carboxyl functionalisation of the GCE surface was not extensive, the resultant electrode surface was stable.

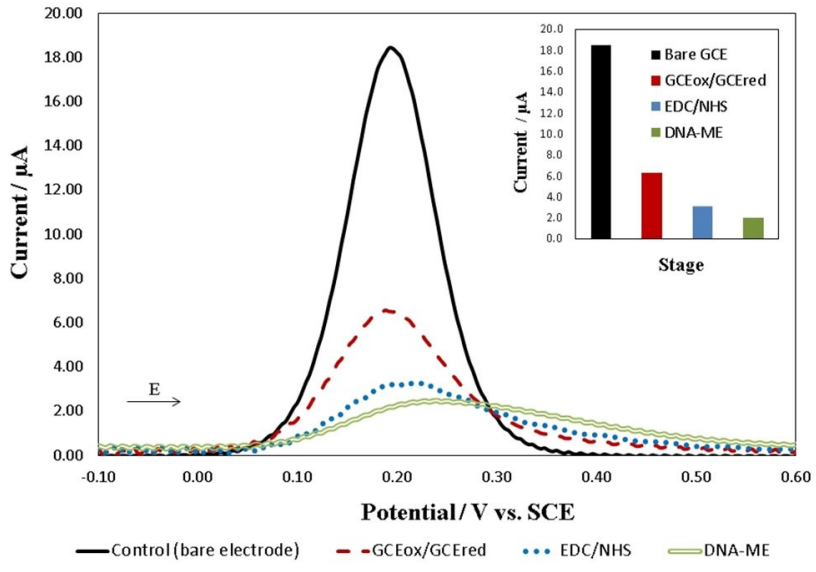

Fig. 3. Background subtracted SW voltammograms registered in $0.05 \mathrm{M}$ phosphate buffer (PB), pH 7.0, containing $0.5 \mathrm{mM}\left[\mathrm{Fe}^{\mathrm{II}}\right.$ $\left.(\mathrm{CN})_{6}\right]^{4-}$ at the bare GCE (black solid trace), GCEox/GCEred (red dashed trace), GCE modified with EDC/NHS linker (blue dotted trace), DNA-GCME $\mathrm{CA}_{\mathrm{C}}$ (green, double trace). Inset: Column graph representing results obtained for all electrode modification stages. 


\subsubsection{Covalent Attachment of the EDC/NHS Linker}

The carboxyl group-functionalised GCE (GCEox/ GCEred) can be used as a platform to attach the EDC/ NHS linker to the electrode surface $[46,69,73]$. EDC is a well known, water-soluble carbodiimide that mediates the formation of an amide link between carboxyl and amine groups. NHS greatly enhances the coupling efficiency of this reaction. The optimal $\mathrm{pH}$ for the EDC coupling reaction is between 4.7 and 6.0, while the optimal $\mathrm{pH}$ for the NHS coupling reaction is approximately 7.0 [62].

The carboxyl group-functionalised GC electrode was immersed in $0.05 \mathrm{M} \mathrm{PB}, \mathrm{pH} 7.0$, containing $10 \mathrm{mM}$ EDC and $10 \mathrm{mM}$ NHS for 40 minutes. Later the electrode was removed, washed and characterised using $\left[\mathrm{Fe}^{\mathrm{II}}(\mathrm{CN})_{6}\right]^{4-}$. After the attachment of the EDC/NHS linker, the [Fe ${ }^{\mathrm{II}}$ $\left.(\mathrm{CN})_{6}\right]^{4-}$ oxidation peak current decreased slightly (Figure 3). The EDC/NHS-modified electrode is expected to sterically hinder redox indicator access to the electrode surface. Further increasing the EDC and NHS concentrations, in this coupling reaction, did not influence the $\left[\mathrm{Fe}^{\mathrm{II}}(\mathrm{CN})_{6}\right]^{4-}$ oxidation peak current $(\mathrm{S}-9, \mathrm{SI})$. The $\left[\mathrm{Fe}^{\mathrm{II}}\right.$ $\left.(\mathrm{CN})_{6}\right]^{4-}$ oxidation peak current did decrease when the coupling reaction time was extended from 20 minutes to 40 and 60 minutes (S-9, SI). However, electrode instability was observed when the coupling reaction time was $\geq 60$ minutes, likely due to the degradation of the linker on the electrode surface, albeit, the half-life of the NHS ester almost two hours at $25^{\circ} \mathrm{C}, \mathrm{pH} 7.0$ [74].

Hence, immersing the pre-treated GC electrode in $0.05 \mathrm{M} \mathrm{PB}, \mathrm{pH} 7.0$, containing $10 \mathrm{mM}$ EDC and $10 \mathrm{mM}$ NHS for 40 minutes were chosen as the parameters for attaching the linker and this procedure enabled the creation of a stable NHS-ester functionalised electrode.

\subsubsection{Covalent Attachment of ST DNA to the EDC/NHS Linker}

The EDC/NHS linker-modified GCE were immersed in $0.09 \mathrm{~g} / \mathrm{L} \mathrm{ST}$ DNA solutions to create DNA-GCME $\mathrm{CA}_{\text {. The }}$ ST DNA used in this work is fragmented (S-10, SI) and some free primary amines are expected to be present in the structure. After the attachment of ST DNA, the [Fe ${ }^{I I}$ $\left.(\mathrm{CN})_{6}\right]^{4-}$ oxidation peak current decreased slightly and shifted to more positive potentials (Figure 3 ). Immersion of the electrode in the ST DNA solution for longer than 30 minutes did not reduce the $\left[\mathrm{Fe}^{\mathrm{II}}(\mathrm{CN})_{6}\right]^{4-}$ electrochemical response $(\mathrm{S}-11, \mathrm{SI})$. The difference between the electrochemical response of the redox indicator at the control and DNA-GCME $\mathrm{CA}_{\mathrm{A}}$ shows that ST DNA had covalently attached to the EDC/NHS linker blocking, to some extent, redox indicator access to the electrode surface. Nevertheless, the immobilised DNA layer did not cover whole electrode surface, allowing direct redox indicator interaction with unmodified areas of the electrode.

\subsection{Characterisation of DNA-AuME}

Self-assembled monolayer (SAM) formation, using thiolmodified DNA at gold electrodes is a one-step immobilisation method that requires careful consideration of some key conditions. In particular, the composition and ionic strength of the immobilisation solution [43], time of immobilisation [24] and the cleanliness and roughness of the electrode surface can affect the integrity of the resultant SAM [75-77]. The conditions commonly reported in the literature are briefly reviewed in S-12, SI.

DNA-ME created on gold electrodes are usually backfilled with alkanethiols, such as 6-mercaptohexanol, to block pin holes between DNA strands. The DNAAuME prepared here were backfilled with p-toluenethiol as aromatic thiols, are reported to be more effective backfilling agents than alkanethiols [49]. The experiments performed by these authors also confirms that p-toluenethiol creates a self-assembled monolayer that covers the electrode surface and blocks the electron transfer between the electrode and redox indicator more effectively than the commonly used 6-mercaptohexanol (S-13, SI and [44]).

The DNA-AuME were characterised in $0.05 \mathrm{M} \mathrm{PB}$, $\mathrm{pH} 7.0$, using ferrocyanide. The repulsion of ferrocyanide ions was clearly observed using cyclic voltammetry (Figure 4). At the bare electrode well defined oxidation $\left(E_{p}\right.$, $\left.{ }_{a}=0.22 \mathrm{~V}\right)$ and reduction $\left(\mathrm{E}_{\mathrm{p}, \mathrm{c}}=0.14 \mathrm{~V}\right)$ peaks are observed for the $\left[\mathrm{Fe}^{\mathrm{II} / \mathrm{III}}(\mathrm{CN})_{6}\right]^{4-/ 3-}$ redox couple. The returned $\Delta \mathrm{Ep}$ value of $79 \mathrm{mV}$ and an $\mathrm{I}_{\mathrm{p}, \mathrm{a}} / \mathrm{I}_{\mathrm{p}, \mathrm{c}}$ ratio of 0.99 , indicates that a near reversible redox process occurs at the bare gold electrode at this scan rate. On the other hand, at the DNA-AuME, a small ill-defined oxidation wave was observed at $+0.42 \mathrm{~V}$ vs. SCE, while no reduction event was evident within the potential window. These changes in the electrochemical profile indicate that non DNA-specific interactions are strongly suppressed at the DNA-AuME. Full repulsion of $0.1 \mathrm{mM}\left[\mathrm{Fe}^{\mathrm{II}}(\mathrm{CN})_{6}\right]^{4-}$ by the DNA layer was previously reported by Kelley et al. [78] at DNA sensors created through chemisorption of thiol-modified Oligo DNA.

The $\left[\mathrm{Fe}^{\mathrm{II}}(\mathrm{CN})_{6}\right]^{4-}$ oxidation peak currents did not alter significantly over time and, after equilibration, returned an average steady-state value of $0.50 \mu \mathrm{A}(\mathrm{S}-14, \mathrm{SI})$. These data suggest that DNA-AuME are stable and repeatable over time.

\subsection{Analysis of DNA Layer Integrity}

The integrity of each DNA layer was estimated as a percentage using the equation presented in 2.7 (Figure 3 for DNA-GCME $\mathrm{CA}_{\mathrm{CA}}$ and Figure 5; Table 1). The oxidation of the anionic ferrocyanide is inhibited in the presence of the negatively charged DNA layer - the degree of this inhibition is largely dependent on the extent of DNA surface coverage. The DNA layers created through physical adsorption, covalent binding and electrochemical adsorption onto glassy carbon electrodes rejected $92 \%$, 


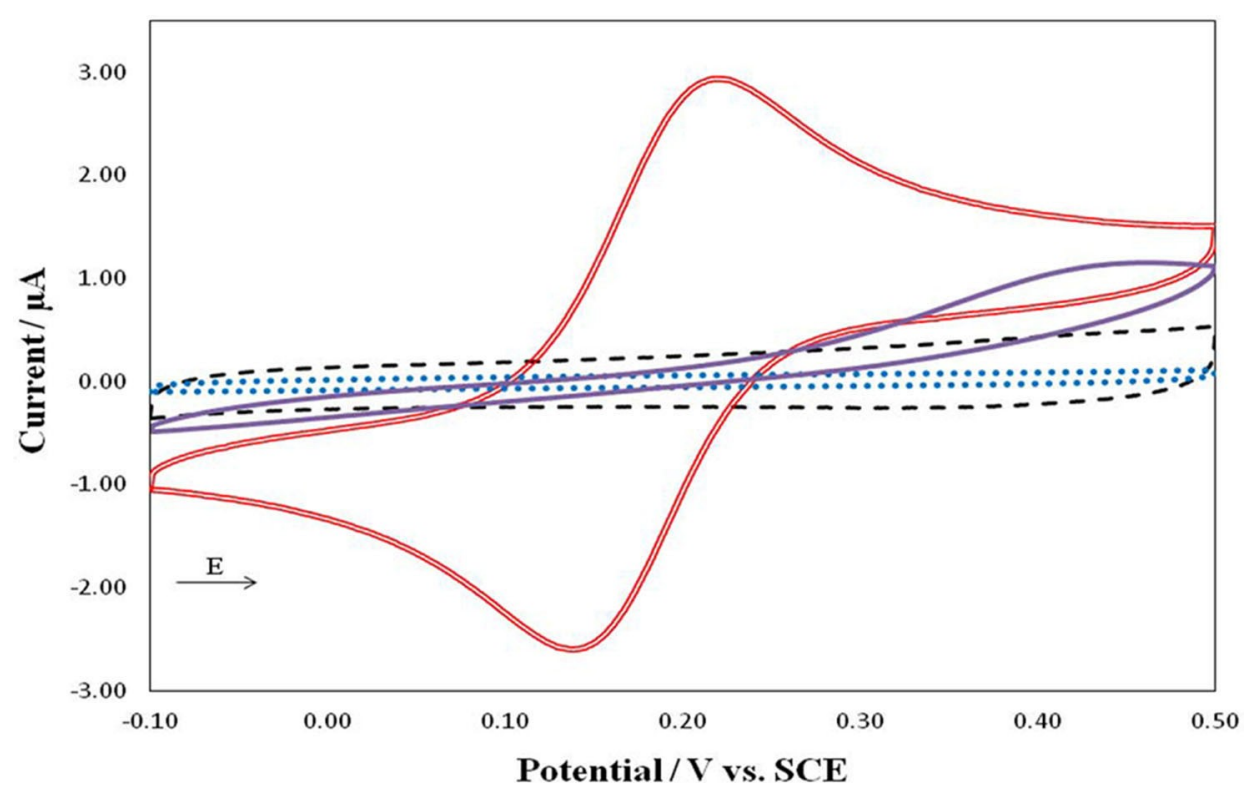

Fig. 4. Cyclic voltammograms registered in $0.05 \mathrm{M} \mathrm{PB}, \mathrm{pH} 7.0$, at the bare AuE (black dashed trace) and at the DNA-AuME (blue dotted trace), and in $0.5 \mathrm{mM}\left[\mathrm{Fe}^{\mathrm{II}}(\mathrm{CN})_{6}\right]^{4-}$ at the bare AuE (red double trace) and at the DNA-AuME (violet solid trace), scan rate: $0.1 \mathrm{~V} / \mathrm{s}$.

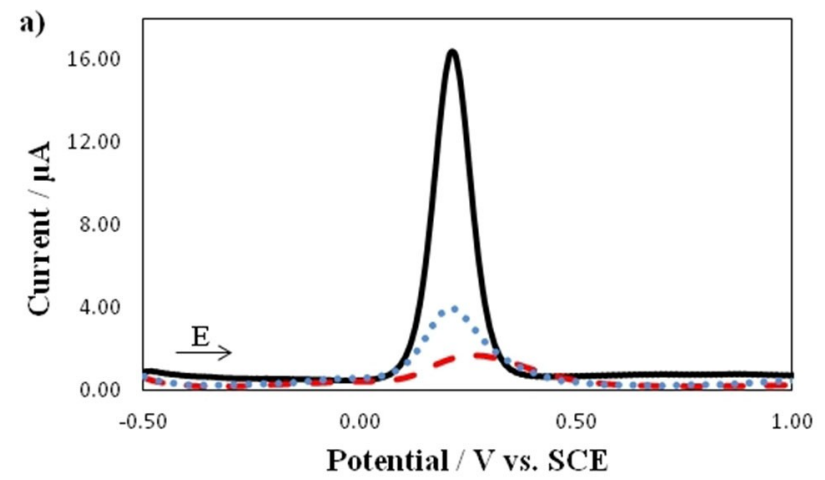

b)

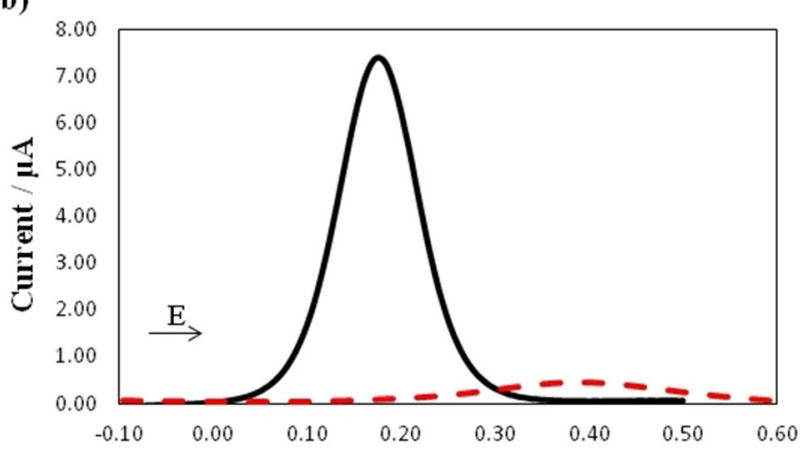

Potential / V vs. SCE

Fig. 5. Background subtracted SW voltammograms registered in a) $0.2 \mathrm{M} \mathrm{AcB}\left(\mathrm{Mg}^{2+}\right), \mathrm{pH} 5.0$, containing $0.5 \mathrm{mM}\left[\mathrm{Fe}^{\mathrm{II}}(\mathrm{CN})_{6}\right]^{4-}$ at the bare GCE (black solid trace) and at the DNA-GCME ${ }_{\mathrm{PA}}$ (red

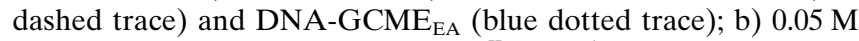
$\mathrm{PB}, \mathrm{pH} 7.0$, containing $0.5 \mathrm{mM}\left[\mathrm{Fe}^{\mathrm{II}}(\mathrm{CN})_{6}\right]^{4-}$ at the bare $\mathrm{AuE}$ (black solid trace), and at the DNA-AuME (red dashed trace). Pulse amplitude $0.025 \mathrm{~V}$, pulse width $33 \mathrm{~ms}$.
$87 \%$ and $78 \%$ of the redox probe activity, respectively. The ferrocyanide peak was almost totally inhibited (94\%) at the DNA-AuME, compared to those obtained at the bare electrodes. In addition, the ferrocyanide oxidation peak observed at the DNA-AuME was significantly shifted to more positive potentials. These data confirm that the gold electrode was effectively modified with DNA and the backfilling agent, suppressing direct electron transfer between ferrocyanide and the electrode surface.

\subsection{Summary of the DNA Layers Immobilisation using Different Methods}

DNA-modified electrodes created on different substrates (carbon and gold) and using different types of DNA (ST DNA and Oligo DNA) are not directly comparable but their suitability for use as analytical sensors was scrutinised.

A summary of potential and current values for the [Fe $\left.{ }^{\mathrm{II}}(\mathrm{CN})_{6}\right]^{4-}$ redox indicator, obtained using cyclic voltammetry at the bare and DNA-modified electrodes, are presented in Table 2.

The $\Delta \mathrm{Ep}$ values (Table 2) and the degree of repulsion presented in Table 1 indicate that DNA-GCME $E_{\mathrm{PA}}$ and DNA-GCME $E_{C A}$ exhibit a relatively high efficiency in blocking the interactions between the redox indicator and the electrode surface, while the DNA-GCME $E_{\mathrm{EA}}$ was the least effective. However, the appearance of well-developed $\left[\mathrm{Fe}^{\mathrm{II} / \mathrm{III}}(\mathrm{CN})_{6}\right]^{4-/ 3-}$ redox peaks at the DNA sensors, prepared using glassy carbon electrodes, indicate that unmodified active sites are present on the electrode surface. Thus, the redox indicator interacted directly with 
Table 1. The percentage amount of $\left[\mathrm{Fe}^{\mathrm{II}}(\mathrm{CN})_{6}\right]^{4-}$ repulsion with associated standard deviation values, obtained from $\mathrm{SW}$ voltammograms. The $\mathrm{I}_{\mathrm{p}}$, bare obtained for GCE was $15.88 \mu \mathrm{A}$ in $\mathrm{AcB}$ and $18.40 \mu \mathrm{A}$ in $\mathrm{PB}$, while for $\mathrm{AuE}$ was $7.39 \mu \mathrm{A}$ in $\mathrm{PB}$.

\begin{tabular}{|c|c|c|}
\hline Method & Oxidation current $/ \mu \mathrm{A}$ & Percentage $\left[\mathrm{Fe}^{\mathrm{II}}(\mathrm{CN})_{6}\right]^{4-}$ repulsion \\
\hline DNA-GCME $\mathrm{PA}_{\mathrm{PA}}$ (in $\mathrm{AcB}$ ) & $1.24+/-0.02$ & $92+/-0.10 \%$ \\
\hline DNA-GCME $\mathrm{EA}_{\mathrm{A}}$ (in $\left.\mathrm{AcB}\right)$ & $3.49+/-0.11$ & $78+/-0.69 \%$ \\
\hline DNA-GCME $E_{\mathrm{CA}}$ (in PB) & $2.34+/-0.02$ & $87+/-0.11 \%$ \\
\hline DNA-AuME (in PB) & $0.47+/-0.03$ & $94+/-0.71 \%$ \\
\hline
\end{tabular}

Table 2. The potential and current values for the $\left[\mathrm{Fe}^{\mathrm{II}}(\mathrm{CN})_{6}\right]^{4-}$ redox wave measured at the bare and DNA-modified electrodes.

\begin{tabular}{lllll}
\hline Method & $\mathrm{E}_{\mathrm{p}, \mathrm{a}} / \mathrm{mV}$ & $\mathrm{E}_{\mathrm{p}, \mathrm{c}} / \mathrm{mV}$ & $\Delta \mathrm{E} / \mathrm{mV}$ & $\mathrm{I}_{\mathrm{p}, \mathrm{a}} / \mathrm{I}_{\mathrm{p}, \mathrm{c}}$ \\
\hline Bare GCE in AcB & 253 & 171 & 82 & 0.94 \\
DNA-GCME $_{\mathrm{PA}}$ (AcB) & 357 & 6 & 351 & 0.79 \\
DNA-GCME $_{\mathrm{EA}}$ (AcB) & 291 & 66 & 225 & 1.12 \\
Bare GCE in PB $^{\text {DNA-GCME }}$ (PA & 265 & 105 & 160 & 1.10 \\
DNA $_{\text {Bare AuE in PB }}$ & 365 & 43 & 322 & 0.76 \\
DNA-AuME (PB) & 218 & 139 & 79 & 0.99 \\
\hline
\end{tabular}

the bare electrode surface and, consequently, these modified electrodes are deemed unsuitable for use as sensors in the detection of interactions between DNA and small molecules (drugs, carcinogens). Moreover, the DNA layers at the DNA-GCME $E_{\mathrm{PA}}$ and DNA-GCME $\mathrm{EA}_{\mathrm{E}}$ desorbed over time (S-5 and S-7, SI). Despite the relatively high implied DNA surface coverages, stability issues observed with the DNA-ME indicate that data gleaned is unreliable - recorded changes in the electrochemical responses registered at the DNA-ME, in the presence of target species, are complicated due to the concurrent desorption of DNA.

The absence of ferrocyanide reduction, coupled to the diminished and shifted oxidation wave at DNA-AuME, ascribed to the high degree of ferrocyanide repulsion, indicate that non DNA-specific interactions are almost totally suppressed at this sensor. Moreover, the DNA layer at DNA-AuME is highly stable and DNA desorption was not observed (S-14, SI). Consequently, the resultant DNA-AuME is suitable for subsequent use in analytical sensor applications.

\section{Conclusions}

The critical step in the creation of a DNA sensor is to immobilise the DNA layer onto the surface in an optimal way. Extensive and ordered DNA surface coverage is necessary in facilitating the desired high reactivity, accessibility and stability of the immobilised DNA. Coupled to this, DNA sensors must negate non DNAspecific binding and direct electron transfer between target molecules and the bare electrode surface. The critical features of DNA layers should always be evaluated before further analytical employment to ensure that subsequent results are reliable.
Ferrocyanide, a widely-used redox indicator, is applicable for the rapid and straightforward examination of the integrity, implied extent of surface coverage and stability of immobilised DNA layers. The presented data shows how various standard DNA immobilisation protocols result in DNA layers of differing stability and coverages. Evidently, standard immobilisation methods can result in the creation of DNA sensors with compromised DNA layers. We hope these data will encourage other research groups to interrogate immobilised DNA layers prior to DNA sensor application, thus ensuring reliable data is gleaned.

\section{Acknowledgements}

Anna Banasiak acknowledges PhD scholarship awarded by the Technological University Dublin (Fiosraigh Award, Grant code: PB03979). This work was performed in the Applied Electrochemistry Group Lab, FOCAS Institute, Technological University Dublin, City Campus - Dublin 8.

\section{References}

[1] L. Wu, X. Lu, J. Jin, H. Zhang, J. Chen, Biosens. Bioelectron. 2011, 26, 4040-4045.

[2] J. Wang, G. Rivas, D. Luo, X. Cai, F. S. Valera, N. Dontha, Anal. Chem. 1996, 68, 4365-4369.

[3] B. Dogan-Topal, B. Uslu, S. A. Ozkan, Biosens. Bioelectron. 2009, 24, 2358-2364.

[4] S. Rauf, J. J. Gooding, K. Akhtar, M. A. Ghauri, M. Rahman, M. A. Anwar, A. M. Khalid, J. Pharm. Biomed. Anal. 2005, 37, 205-217.

[5] J. Labuda, R. Ovádeková, J. Galandová, Microchim. Acta. 2009, 164, 371-377.

[6] K. Lozano Untiveros, E. G. da Silva, F. C. de Abreu, E. F. da Silva-Júnior, J. X. de Araújo-Junior, T. Mendoça de Aquino, S. M. Armas, R. O. de Moura, F. J. B. MendonçaJunior, V. L. Serafim, K. Chumbimuni-Torres, Biosens. Bioelectron. 2019, 133, 160-168.

[7] E. M. Boon, J. E. Salas, J. K. Barton, Nat. Biotechnol. 2002, 20, 282-286.

[8] E. Kerman, K. Morita, Y. Takamura, Y. Tamiya, Anal. Bioanal. Chem. 2005, 381, 1114-1121.

[9] J. Labuda, M. Bučková, L. Heilerová, S. Šilhár, I. Štepánek, Anal. Bioanal. Chem. 2003, 376, 168-173.

[10] L. Heilerová, M. Bučková, P. Tarapčík, S. Šilhár, J. Labuda, Czech J. Food Sci. 2018, 21, 78-84.

[11] F. Davis, M. A. Hughes, A. R. Cossins, S. P. J. Higson, Anal. Chem. 2007, 79, 1153-1157 . 
[12] E. M. Boon, D. M. Ceres, T. G. Drummond, M. G. Hill, J. K. Barton, Nat. Biotechnol. 2000, 18, 1096-1100.

[13] R. Miranda-Castro, R. Sánchez-Salcedo, B. Suárez-Álvarez, N. de-los-Santos-Álvarez, A. J. Miranda-Ordieres, M. Jesús Lobo-Castañón, Biosens. Bioelectron. 2017, 92, 162-170.

[14] A. W. Peterson, R. J. Heaton, R. M. Georgiadis, Nucleic Acids Res. 2001, 29, 5163-5168.

[15] V. Biagiotti, A. Porchetta, S. Desiderati, K. W. Plaxco, G. Palleschi, F. Ricci, Anal. Bioanal. Chem. 2012, 402, 413-421.

[16] A. M. Oliveira-Brett, V. C. Diculescu, Bioelectrochemistry. 2004, 64, 143-150.

[17] T. Gu, H. Q. Xia, Y. Hu, Y. Jiang, Anal. Sci. 2018, 34, 11311135.

[18] F. C. Abreu, M. O. F. Goulart, A. M. Oliveira Brett, Biosens. Bioelectron. 2002, 17, 913-919.

[19] A. M. Chiorcea, A. M. O. Brett, Bioelectrochemistry. 2004, 63, 229-232.

[20] X. Lu, Y. Chen, J. Chen, Y. Zhang, L. Zhang, M. Li, Int. J. Electrochem. Sci. 2006, 1, 130-138.

[21] A. M. Oliveira-Brett, A. M. Chiorcea, Langmuir. 2003, 19, 3830-3839.

[22] E. Paleček, F. Jelen, Crit. Rev. Anal. Chem. 2002, 32, 261270.

[23] C. M. A. Brett, A. M. Oliveira Brett, S. H. P. Serrano, Electrochim. Acta. 1999, 44, 4233-4239.

[24] A. B. Steel, R. L. Levicky, T. M. Herne, M. J. Tarlov, Biophys. J. 2000, 79, 975-981.

[25] Y.-D. Zhao, D.-W. Pang, Z.-L. Wang, J.-K. Cheng, Y.-P. Qi, J. Electroanal. Chem. 1997, 431, 203-209.

[26] M. I. Pividori, A. Merkoçi, S. Alegret, Biosens. Bioelectron. 2000, 15, 291-303.

[27] A. Erdem, K. Kerman, B. Meric, M. Ozsoz, Electroanalysis. 2001, 13, 219-223.

[28] P. Kara, K. Kerman, D. Ozkan, B. Meric, A. Erdem, Z. Ozkan, M. Ozsoz, Electrochem. Commun. 2002, 4, 705-709.

[29] M. Mascini, I. Palchetti, G. Marrazza, Fresenius J. Anal. Chem. 2001, 369, 15-22.

[30] J. Wang, E. Palecek, P. E. Nielsen, G. Rivas, X. Cai, H. Shiraishi, N. Dontha, D. Luo, P. A. M. Farias, J. Am. Chem. Soc. 1996, 118, 7667-7670.

[31] V. C. Diculescu, A. M. C. Paquim, A. M. O. Brett, Sensors. 2005, 5, 377-393.

[32] A. M. Oliveira-Brett, S. H. P. Serrano, J. Braz. Chem. Soc. 1995, 6, 97-100.

[33] C. M. A. Brett, A. M. Oliveira-Brett, S. H. P. Serrano, J. Electroanal. Chem. 1994, 366, 225-231.

[34] K. J. Odenthal, J. J. Gooding, Analyst. 2007, 132, 603-610.

[35] F. Lucarelli, G. Marrazza, A. P. F. Turner, M. Mascini, Biosens. Bioelectron. 2004, 19, 515-530.

[36] J. I. A. Rashid, N. A. Yusof, Sens. Bio-Sensing Res. 2017, 16, 19-31.

[37] T. G. Drummond, M. G. Hill, J. K. Barton, J. Am. Chem. Soc. 2004, 126, 15010-15011.

[38] H. O. Finklea, in Electroanalytical Chemistry: A Series of Advances, 1st ed., Vol.19 (Eds.: A.J. Bard, I.Rubinstein), Marcel Dekker Inc, 1996, pp. 160-166.

[39] Y. D. Zhao, D. W. Pang, S. Hu, Z. L. Wang, J. K. Cheng, H. P. Dai, Talanta. 1999, 49, 751-756.

[40] L. Zhu, R. Zhao, K. Wang, H. Xiang, Z. Shang, W. Sun, Sensors. 2008, 8, 5649-5660.

[41] T. M. Herne, M. J. Tarlov, J. Am. Chem. Soc. 1997, 119, 8916-8920.

[42] T. Liu, J. K. Barton, J. Am. Chem. Soc. 2005, 127, 1016010161.

[43] D. Jambrec, M. Gebala, F. La Mantia, W. Schuhmann, Angew. Chemie - Int. Ed. 2015, 54, 15064-15068.
[44] A. Banasiak, J. Cassidy, J. Colleran, Biosens. Bioelectron. 2018, 117, 217-223.

[45] F. T. Huey, H. Gong, X. D. Dong, X. Zeng, A. L. K. Tan, X. Yang, N. T. Swee, Anal. Chim. Acta. 2005, 551, $23-29$.

[46] K. Kerman, D. Ozkan, P. Kara, B. Meric, J. J. Gooding, M. Ozsoz, Anal. Chim. Acta. 2002, 462, 39-47.

[47] M. Amouzadeh Tabrizi, M. Shamsipur, Biosens. Bioelectron. 2015, 69, 100-105.

[48] C. Ge, J. Liao, W. Yu, N. Gu, Biosens. Bioelectron. 2003, 18, 53-58.

[49] S. Moura-Melo, R. Miranda-Castro, N. De-Los-SantosÁlvarez, A. J. Miranda-Ordieres, J. R. Dos Santos Junior, R. A. Da Silva Fonseca, M. J. Lobo-Castañón, Anal. Chem. 2015, 87, 8547-8554.

[50] M. Sánchez-Paniagua, S. Palenzuela-Batista, C. L. Manzanares-Palenzuela, B. López-Ruiz, Talanta. 2020, 212, 120735.

[51] K. Hashimoto, K. Miwa, M. Goto, Y. Ishimori, Supramol. Chem. 1993, 2, 265-270.

[52] CRC Handbook of Chemistry and Physics, 95th ed., (Eds.: W. M. Haynes), CRC/Taylor Fr., 2015.

[53] H. Teymourian, A. Salimi, S. Khezrian, Electroanalysis. 2017, 29, 409-414.

[54] M. P. Pujado, Carbon Nanotubes as Platforms for Biosensors with Electrochemical and Electronic Transduction, 1st ed., Springer-Verlag Berlin Heidelberg, 2012, pp. 106.

[55] L. G. Carrascosa, L. Martínez, Y. Huttel, E. Román, L. M. Lechuga, Eur. Biophys. J. 2010, 39, 1433-1444.

[56] V. Dharuman, J. H. Hahn, Sensors Actuators, B Chem. 2007, 127, 536-544.

[57] D. Erts, B. Polyakov, H. Olin, E. Tuite, J. Phys. Chem. B. 2003, 107,3591-3597.

[58] S. O. Kelley, J. K. Barton, N. M. Jackson, L. D. McPherson, A. B. Potter, E. M. Spain, M. J. Allen, M. G. Hill, Langmuir. 1998, 14, 6781-6784.

[59] Z. L. Zhang, D. W. Pang, R. Y. Zhang, J. W. Yan, B. W. Mao, Y. P. Qi, Bioconjug. Chem. 2002, 13, 104-109.

[60] A. Ulianas, L. Y. Heng, S. A. Hanifah, T. L. Ling, Sensors. 2012, 12, 5445-5460.

[61] X. Bin, H. Kraatz, Analyst. 2009, 134, 1309-1313.

[62] G. T. Hermanson, Bioconjugate Techniques, 2nd ed., Academic Press, 2008.

[63] P. R. Solanki, N. Prabhakar, M. K. Pandey, B. D. Malhotra, Biomed. Microdevices. 2008, 10, 757-767.

[64] M. Guo, J. Chen, D. Liu, L. Nie, S. Yao, Bioelectrochemistry. 2004, 62, 29-35.

[65] S. Nur Topkaya, S. Aydinlik, N. Aladag, M. Ozsoz, D. Ozkan-Ariksoysal, Comb. Chem. High Throughput Screen. 2012, 13, 582-589.

[66] G. H. Karpen, Cold Spring Harb. Protoc. 2009, 4.

[67] H. C. Birnboim, Methods Enzymol. 1992, 216, 154-160.

[68] G. C. Saunders, J. M. Rossiin Essentials Nucleic Acid Analysis A Robust Approach, 1st ed., (Eds.: J. T. Keer, L. Birch), RSC Publishing, 2008, pp. 60-71.

[69] K. M. Millan, A. J. Spurmanis, S. R. Mikkelsen, Electroanalysis. 1992, 4, 929-932.

[70] Q. L. Zhao, Z. L. Zhang, L. Bao, D. W. Pang, Electrochem. Commun. 2008, 10, 181-185.

[71] D. E. Aydemir, N. McArdle, H. Patel, S. Whitford, W. Evans, C. W. Travas-Sejdic, J. Williams, Anal. Chem. 2015, 87, 5189-5197.

[72] J. Spires, J. B. Peng, H. Williams, D. E. Wright, B. E. Soeller, C. Travas-Sejdic, Biosens. Bioelectron. 2008, 24, 928-933.

[73] M. L. Pedano, G. A. Rivas, Sensors. 2005, 5, 424-447.

[74] J. V. Staros, Acc. Chem. Res. 1988, 21, 435-441. 
[75] R. F. Carvalhal, R. S. Freire, L. T. Kubota, Electroanalysis. 2005, 17, 1251-1259.

[76] J. C. Hoogvliet, M. Dijksma, B. Kamp, W. P. Van Bennekom, Anal. Chem. 2000, 72, 2016-2021.

[77] E. F. Douglass, P. F. Driscoll, D. Liu, N. A. Burnham, C. R. Lambert, W. G. McGimpsey, Anal. Chem. 2008, 80, 76707677.
[78] S. O. Kelley, J. K. Barton, N. M. Jackson, M. G. Hill, Bioconjug. Chem. 1997, 8, 31-37.
Received: June 8, 2020

Accepted: June 24, 2020

Published online on July 14, 2020 